\title{
Batik Pring: Sejarah Perkembangan Batik Modern Desa Sidomukti Tahun 2002-2015 Kecamatan Plaosan Kabupaten Magetan
}

\author{
Nia Ulfia Krismawati*
}

\begin{abstract}
Abstrak
Penelitian ini bertujuan untuk mengetahui sejarah perkembangan industri batik dan perkembangan motif batik. Lokasi penelitian di Desa Sidomukti Kecamatan Plaosan Kabupaten Magetan, khususnya di dua kelompok usaha bersama (KUBE) yaitu KUBE Mukti Rahayu dan Mukti Lestari. Penelitian ini menggunakan pendekatan Kualitatif dengan jenis penelitian deskriptif. Sumber data penelitian ini adalah data primer yang diperoleh dari lokasi penelitian berupa wawancara dengan pendiri dan pembatik dan dokumentasi. Data sekunder berupa studi pustaka yang terkait dengan sejarah perkembangan industri batik di Desa Sidomukti.

Hasil penelitian menunjukkan bahwa Industri Batik Pring Desa Sidomukti didirikan pada tahun 2002 oleh kepala desa yang bernama Pak Tikno, KUBE pertama yang didirikan diberi nama Mukti Rahayu dengan anggota sebanyak 36 pembatik. Pada tahun 2006 didirikan KUBE baru dengan nama Mukti Lestari yang beranggotakan 30 orang. Pada tahun 2014 mulai dirintis KUBE baru yang diberi nama Sri Tanjung yang mempunyai konsep berbeda dari 2 KUBE sebelumnya. Perkembangan industri diiringi dengan perkembangan motif batik diantaranya Motif Batik Pring Sedapur, Pring Sulur, Bambu Batu, Pring Bonggolan, Jalak Lawu, Pring Ijen, Pring Sekar Jagad, Pring Sekar Melati, Pring Bunga, Pring Kipas, Pring Cecek, Pring Kuning, Magetan Kumandang, Pring Polos, Bambu Rumput, Pring Gunungan, Pring Naga, Pring Bunga Krisan, dan Pring Parang Garuda. Pembuatan Batik Pring Sidomukti dari segi pembuatan, masih dengan teknik tradisional yaitu teknik tulis yang memberikan kesan batik yang sebenarnya.
\end{abstract}

Kata Kunci: Industri, Batik Pring, Desa Sidomukti

\section{Pendahuluan}

Batik merupakan hasil budaya masyarakat Indonesia dan menjadi salah satu kekayaan Nusantara. Batik adalah sebuah hasil karya manusia yang berupa kerajinan bernilai seni tinggi.Pada dasarnya batik merupakan bahan kain yang erat hubungannya dengan nilai budaya masyarakat yang merupakan hasil budaya dari masyarakat (Lisbijanto, 2013: 7). Pada masa lampau pembuatan batik dijadikan sebagai mata pencaharian oleh perempuan Jawa. Desa Sidomukti merupakan salah satu desa yang mempunyai potensi akan batik pada tahun 1970an. Batik yang diproduksi adalah batik klasik yang biasa digunakan oleh keluarga keraton.

Batik klasik merupakan sebuah kain yang diproses menggunakan canting dan malam dan membutuhkan waktu yang relatif lama. Namun proses tersebutlah yang menjadikan batik ini mempunyai nilai dan harga jual yang tinggi. Menurut Karmila (2010: 9) mengemukakan Batik adalah suatu kegiatan yang berawal dari menggambar suatu bentuk misalnya ragam 
hias di sehelai kain dengan menggunakan lilin batik (malam), kemudian diteruskan dengan pemberian makna.Menurut pernyataan tersebut dapat disimpulkan bahwa setiap batik yang dibuat mempunyai motif yang cantik dan bermakna.

Motif dari satu daerah dengan daerah lainpun mempunyai karakteristik yang berbeda. Hal tersebut didukung oleh pernyataan dari Wulandari (2011: 9) bahwa corak dan motif batik tidak dapat dilepaskan dari unsur-unsur yang melekat dari wilayah asal pembuatannya. Sebuah motif batik pada awalnya menunjukkan sebuah status sosial di dalam masyarakat Jawa.

Penggunaannya didasarkan pada status sang pengguna seperti motif yang berbeda dari batik klasik yang digunakan oleh anggota keraton berbeda dengan batik yang dikenakan oleh masyarakat biasa. Namun, pada perkembangannya pemakaian batik mengalami perubahan dari pemakaian berdasarkan aturan-aturan menjadi pemakaian secara bebas.

Pada tahun 1970an aktifitas membatik masih menjadi mayoritas pekerjaan perempuan di Desa Sidomukti. Namun seiring perkembangan zaman hal tersebut berubah dikarenakan industri batik kalah bersaing dengan industri rumahan. Magetan merupakan sebuah kabupaten yang terkenal dengan industri rumahan seperti industri kulit, makanan ringan, dan anyaman. Batik lambat laun mengalami kepunahan dan kemudian terlupakan dalam ingatan masyarakat Desa Sidomukti. Berangkat dari permasalahan tersebut dan dengan rendahnya pendapatan masyarakat Desa Sidomukti membuat seorang kepala desa yang bernama Pak Tikno berinisiatif untuk mendirikan kembali industri nenek moyang yang telah lama mati.

Gagasan dari kepala desa ini pada akhirnya dapat terealisasikan dengan didirikannya sebuah industri baru yaitu industri batik. Menurut Winjosoebroto (2003:2), Industri diartikan sebagai suatu lokasi atau tempat dimana aktivitas produksi akan diselenggarakan. Sedangkan aktivitas produksi bisa dinyatakan sebagai sekumpulan aktivitas diperlukan untuk mengubah satu kumpulan masukan menjadi bahan keluaran yang memiliki nilai tambah.

Didirikannya kembali indsutri ini diharapkan mampu membawa angin segar bagi perekonomian dan kebudayan yang telah mati. Terdapat beberapa perkembangan yang terjadi di industri yang telah didirikan. Perkembangan mulai dari terbentuknya KUBE dengan jumlah 3 KUBE dan perkembangan dalam hal motif yang khas dari Desa Sidomukti.

Seringkali masyarakat kurang paham terkait batik. Banyak yang menganggap bahwa kain yang bermotif batik adalah kain batik. Menurut Hamidin (2010: 7) Batik berasal dari 'amba' (Jawa), yang artinya menulis dan 'nitik'. Kata batik merujuk pada teknik pembuatan corak 
menggunakan canting atau cap dan pencelupan kain, dengan menggunakan bahan perintang warna corak, bernama 'malam' (lilin) yang diaplikasikan di atas kain. Sehingga menahan masuknya bahan pewarna.

Dari pernyataan tersebut dapat disimpulkan bahwa batik merupakan sebuah kain yang memiliki ragam corak yang diproses dengan "malam" dengan menggunakan canting. Sedangkan, pengertian batik dari cara pembuatannya adalah bahan kain yang dibuat dengan cara dua cara yaitu bahan kain yang diwarna dengan menggunakan malam dan bahan kain yang diwarna dengan menggunakan motif-motif tertentu yang sudah lazim (Lisbijanto, 2013: 7).

Dari segi kain yang digunakan batik berbeda dengan kain yang bermotif batik.Kain mori merupakan kain yang dapat digunakan dalam membatik. Ketika menggunakan teknik tulis maka kain yang dapat digunakan adalah kain yang mempunyai serat alami. Maka dari itu perlu ditekankan bahwa kain biasa yang bermotif batik tidak disebut sebagai batik. Hal tersebut dikarenakan proses pembuatannya adalah melalui teknologi berupa komputer sehingga motif yang ada di dalamnya adalah hasil printing dari komputer saja.

Berangkat dari kerancuan yang terjadi pada pemahaman masyarakat maka perlunya sebuah kajian terkait keberadaan batik sebagai hasil karya seni yang bernilai tinggi. Seperti batik pring yang berasal dari Desa Sidomukti yang memiliki keindahan tinggi dan menjadi primadona di hati masyarakat Magetan.

Dalam pembuatannya batik Pring memupunyai makna tertentu yang dapat jadikan sebuah pembelajaran pada masyarakat. Ditambah lagi pengetahuan akan proses berdiri dan berkembangnya industri batik ini dianggap perlu agar masyarakat mengetahui sejarah dibalik pendirian kembali industri nenek moyang dari Desa Sidomukti.

\section{Tinjauan Pustaka}

\section{A. Konsep Industri}

Menurut Kamus Besar Bahasa Indonesia, industri adalah kegiatan memproses atau mengolah barang dengan menggunakan sarana dan peralatan. Industri juga diartikan sebagai segala aktivitas manusia di bidang ekonomi yang produktif dalam proses pengolahan bahan dasar menjadi barang yang bernilai daripada bahan dasarnya untuk dijual.

Menurut Lempelius \& Gert Thoma (1979: 2) terdapat kondisi-kondisi pokok yang menentukan perkembangan usaha industri kecil di daerah pedesaan, yaitu:

1. Ketidakseimbangan antara sektor tradisional dan sektor modern. Industri batik yang terdapat di Desa Sidomukti mengalami kepunahan sekitar tahun 1970 dikarenakan kalah bersaing dengan industri lain seperti industri makanan, bambu dan kulit. Industri tersebut 
memiliki peminat yang lebih banyak dibandingkan dengan peminat batik.

2. Pengaruh kondisi setempat. Kondisi setempat memberikan pengaruh pada perkembangan dari sebuah industri. Desa Sidomukti mempunyai banyak tumbuhan bambuyang dapat dimanfaatkan untuk membuat kerajinan anyaman. Desa Sidomukti mempunyai potensi dalam bidang pertanian. Masyarakat lebih memilih mengembangkan industri anyaman dan pertanian dibandingkan dengan industri batik dikarenakan lebih menjanjikan.

3. Tata ekonomi dan kebijaksanaan pemerintah di sektor perindustrian. Pemerintah Kabupaten Magetan lebih menekankan pada industri kulit, makanan ringan dan pariwisata. Industri Batik Pring kurang diperhatikan sehingga mengalami kepunahan dikarenakan kalah bersaing dengan industri lainnya.

Industri kecil di Indonesia digolongkan berdasarkan eksistensinya ke dalam tiga kategori yaitu industri lokal, industri sentral, dan industri mandiri, yang dapat dijabarkan sebagai berikut ini:

1. Industri lokal adalah kelompok jenis industri yang menggantungkan hidupnya pada pasar setempat yang terbatas, serta dari segi lokasinya. Target pemasarannya terbatas dan hal tersebut dikarenakan oleh penggunaan sarana yang sederhana juga.
2. Industri sentra adalah kelompok jenis industri yang dari segi jenis satuan usahanya mempunyai skala kecil tetapi mengelompok pada kawasan produksi yang terdiri dari kumpulan unit usaha yang menghasilkan barang sejenis. Ditinjau dari segi pemasarannya kelompok industri ini umumnya menjangkau pasar yang lebih luas dari pada jenis industri lokal, sehingga peranan pedagang perantara atau pedagang pengumpul menjadi cukup menonjol.

3. Industri Mandiri dapat dideskripsikan sebagai kelompok jenis usaha yang mempunyai sifat-sifat sebagai industri kecil, namun mempunyai kemampuan adaptasi teknologi yang lebih baik. Pemasaran dari industri ini tidak tergantung pada peranan pedagang perantara. Memang jika dikelompokkan pada industri kecil, industri mandiri ini lebih jika dibandingkan dengan industri kecil lainnya, karena kemampuan dari industri mandiri ini melebihi dua industri kecil lainnya. Faktor perekrutan tenaga kerjalah yang membuat industri mandiri tergolong pada industri kecil (Saleh, 1986: 50-51).

\section{B. Perkembangan Batik}

Batik merupakan bahan kain yang erat hubungannya dengan nilai budaya masyarakat yang merupakan hasil budaya dari masyarakat. Menurut Hamidin (2010: 7) menyatakan bahwa: 
Batik berasal dari 'amba' (Jawa), yang artinya menulis dan 'nitik'.Kata batik merujuk pada teknik pembuatan corak menggunakan canting atau cap dan pencelupan kain, dengan menggunakan bahan perintang warna corak, bernama 'malam' (lilin) yang diaplikasikan di atas kain. Sehingga menahan masuknya bahan pewarna.

Terdapat pembagian batik berdasarkan zamannya yaitu zaman Majapahit dan Islam (Hamidin, 2010: 9), yang dijelaskan sebagai berikut:

1. Batik Zaman Majapahit

Batik mempunyai hubungan erat dengan Kerajaan Majapahit.Keberadaan Majapahit sebagai kerajaan besar, dan makmur ini pernah mengalami kejayaan selama beberapa abad dan membuat tradisi serta kebudayaan yang mengakar kuat di nusantara termasuk seni Batik (Wulandari, 2011: 11).

Batik asli Majapahit dinamakan dengan Batik Kalebret yang mempunyai warna dasar putih dan warna coklat muda serta biru tua hampir sama dengan batik yang berada di Yogyakarta.

2. Batik Zaman Islam

Batik pada zaman Islam erat kaitannya dengan daerah Ponorogo.Awal mula dikenalnya batik di Ponorogo adalah berkat kedatangan dari Putri Keraton Solo yang merupakan istri dari Kyai Hasan Basri ke daerah Ponorogo dengan menggunakan batik sebagai pakaiannya. Banyak dari keluarga kerajaan yang memutuskan belajar di pesantren dengan menggunakan batik yang secara tidak langsung menyebabkan batik dikenal di Ponorogo, bahkan juga mengalami perkembangan.

Para pemuda yang sudah lulus dari pesantren kemudian menyumbangkan ilmu bagaimana cara membuat batik kepada masyarakat. Batik Ponorogo dikenal dengan batik kasarnya yaitu batik cap mori biru dengan menggunakan teknik tradisional yaitu batik tulis (Hamidin, 2010: 11).

Pada era sekarang teknik pembuatan batik kemudian berkembang. Menurut (Kusumawardani, 2012: 23-25) terdapat beberapa jenis batik di Indonesia jika dilihat dari segi teknik pembuatannya yaitu, batik tulis, cap, cap tulis, dan print, yang dapat dijelaskan sebagai berikut:

1. Batik Tulis

Pada awalnya para pengarajin membuat batik dengan cara tulis dengan menggunakan tangan. Pembuatan batik dengan teknik ini membutuhkan waktu yang lama dengan menggunakan pelekatan lilin dan canting tulis untuk menjaga kualitas dan membuat harganya lebih mahal dibandingkan dengan batik yang dibuat dengan teknik lainnya.

2. Batik Cap

Batik cap memiliki kualitas yang jauh berbeda dengan batik tulis karena tingkat kesulitan dan waktu pengerjaan relatif singkat dibandingkan dengan batik tulis. Batik cap digunakan pada 
pemesanan yang bersifat masal dalam artian diproduksi dalam jumlah banyak.

3. Batik Cap Tulis

Cara pembuatan batik ini adalah menggabungkan dua teknik membatik. Batik dibuat dengan cara dicetak, setelah jadi batik ini disempurnakan dengan teknik tulis.

\section{Metode Penelitian}

Penelitian ini menggunakan pendekatan kualitatif. Penelitian kualitatif adalah jenis penelitian yang temuantemuannya tidak diperoleh melalui prosedur statistik dan bentuk hitungan lainnya (Straus \& Juliet, 2007: 4). Pendekatan ini memungkinkan untuk mendapatkan data primer atau langsung dari pelaku utama terkait yang diteliti.Data akhir dari penelitian ini adalah berbentuk deskriptif yaitu dengan menyusunan laporan penelitian dalam bentuk tulisan dan deskripsi terkait hasil penelitian.

Pada penelitian ini seorang informan yang berperan sebagai sumber primer mempunyai posisi penting dalam pengumpulan sumber data penelitian. Hal tersebut dikarenakan informan adalah pelaku utama yang dapat memberikan informasi sebanyak-banyaknya kepada peneliti.

Pendukung dari pernyataan si pelaku utama adalah dokumentasi KUBE berupa SIUP dan dokumen keanggotaan. Teknik yang digunakan oleh peneliti dalam mengumpulkan data adalah teknik observasi dan wawancara mendalam kepada pelaku utama yaitu pendiri industri batik dan para pembatik.

Jenis penelitian adalah deskriptif yang merupakan penelitian yang dimaksudkan untuk mengumpulkan informasi mengenai subjek penelitian dan perilaku dari subjek penelitian pada suatu periode tertentu (Mukhtar, 2013:11). Pengumpulan data dari pelaku utama dimaksudkan agar data yang diperoleh dapat bersifat kongkrit dan akurat terkait sejarah perkembangan industri batik.

\section{Hasil Dan Pembahasan}

\section{A. Sejarah Pendirian Industri Batik Pring Desa Sidomukti}

Magetan merupakan salah satu kabupaten yang terletak di Propinsi Jawa Timur. Magetan terletak di sekitar 7 38' 30" bujur timur, dengan suhu udara berkisar 16-20 $\mathrm{C}$ di daerah pegunungan dan $222^{\circ} 6^{\circ}$ $\mathrm{C}$ di dataran rendah curah hujan yang turun mencapai 1.481-2.345 mm pertahun di dataran tinggi dan 876-1.551 $\mathrm{mm}$ pertahun di dataran rendah. Kabupaten ini terkenal akan potensi industri seperti industri makanan ringan, industri kulit, industri anyaman.

Menurut Winjosoebroto (2003:2) berpendapat bahwa Industri diartikan sebagai suatu lokasi atau tempat dimana aktivitas produksi akan diselenggarakan. Aktivitas produksi bisa dinyatakan sebagai 
sekumpulan aktivitas diperlukan untuk mengubah satu kumpulan masukan menjadi bahan keluaran yang memiliki nilai tambah.

$$
\text { Magetan juga berpotensi dalam }
$$

bidang pertanian. Mayoritas warga Kabupaten Magetan bekerja sebagai petani. Kecamatan Plaosan merupakan salah satu kecamatan yang memiliki potensi pertanian tertinggi dibandingkan dengan kecamatan lainnya, maka dari itu mayoritas penduduk kecamatan Plaosan bekerja sebagai petani.Desa Sidomukti merupakan desa yang terletak di Kecamatan Plaosan, Kabupaten Magetan.

Desa Sidomukti merupakan daerah pegunungan dengan ketinggian $600 \mathrm{~m}$ di atas permukaan laut dengan curah hujan rata-rata $700 \mathrm{~mm}$ setiap tahun dan suhu $29^{\circ}$ C. Kondisi geografis Desa Sidomukti memungkinkan bambu untuk tumbuh. Bambu dapat tumbuh dengan baik pada ketinggian 0-1500 m dari permukaan laut. Terdapat tumbuhan bambu yang tumbuh disepanjang jalan menuju Desa Sidomukti.

Kondisi geografis yang mendukung dimanfaatkan oleh masyarakat untuk membuat suatu hal yang bersifat ekonomis. Banyaknya bambu yang tumbuh disekitar dimanfaatkan oleh masyarakat untuk dijadikan anyaman yang bernilai ekonomis seperti capil, tampah, tumbu dan beberapa bentuk yang lain. Bambu juga menjadi sumber inspirasi dalam pembuatan motif Batik Sidomukti. Desa Sidomukti merupakan desa pembatik,yang sekitar tahun 1970 dikerjakan oleh para wanita. Hal tersebut didukung pernyataan dari Mardiantoro, dkk (2013: 111) bahwa sebenarnya batik khas Magetan Pring Sedapur atau Sidomukti sudah ada sejak tahun 1970-an serta hampir semua warga bisa membatik.Setelah tahun 1970 Industri Batik Sidomukti mengalami kepunahan dikarenakan tidak mampu bersaing dengan industri rumahan lainnya, seperti indutri makanan, kerajinan kulit dan anyaman.

Batik merupakan salah satu kebudayaan asli Indonesia yang harus dilestarikan oleh masyarakat. Tingkat pendapatan ekonomi masyarakat Desa Sidomukti tergolong rendah. Mayoritas warga bekerja sebagai petani karena didukung oleh alam sekitar yang berpotensi akan pertanian. Tanaman pokok yang ditanam adalah padi dan beberapa sayuran, seperti kubis dan wortel. Selain itu, warga Desa Sidomukti mempunyai pekerjaan lain yaitu sebagai penganyam.

Bambu yang banyak tumbuh di Desa ini dimanfaatkan untuk mencari rezeki. Mayoritas ibu rumah tangga bekerja sebagai penganyam yang dilakukan siang dan malam menjadi beberapa benda seperti, caping, topi, baki, kap lampu, tempat tisu, tempat buah, dan tempat koran. Hasil perbulan yang didapatkan oleh warga terbilang hanya sekedar cukup untuk kebutuhan sehari-hari. Pada tahun 1999 seorang kepala desa yang bernama Tikno berinisiatif untuk mendirikan kembali 
industri batik dengan tujuan pelestarian kebudayaan nenek moyang sekaligus sebagai upaya peningkatan penghasilan warga. Kemudian Kepala Desa Sidomukti melakukan kerjasama dengan pemerintah setempat untuk merealisasikan gagasan pendirian Industri Batik Pring Sidomukti.

Keprihatianan terhadap budaya nenek moyang yang terlupakan dan rendahnya perekonomian masyarakat cukup beralasan dalam pendirian industri ini. Selain peningkatan status sosial perempuan Desa Sidomukti juga ikut menjadi pertimbangan. Warga Desa ini tergolong pada golongan menengah ke bawah jika dilihat dari segi pendidikan terakhir dan pendapatan perbulan. Pak Tikno bersama warga bertekad untuk memperbaiki taraf hidup dengan menambah keterampilan dan potensi akan daerah yang dimiliki.

Pada tahun 2002 gagasan tersebut baru dapat terealisasikan setelah dilakukan beberapa pelatihan kepada para warga yang kemudian dinamakan dengan KUBE Mukti Rahayu. Pada tahun 2002 pemerintah memberikan bantuan berupa pelatihan yang diselenggarakan oleh Dinas Sosial setempat, Dinas Perindustrian dan perdagangan serta Dinas Koperasi. Pelatihan ini diikuti oleh warga Desa Sidomukti baik dari kalangan muda sampai kalangan tua dan neneknenek mantan pembatik. Kemudian pemerintah memberikan bantuan berupa dana untuk permodalan dan beberapa fasilitas yang digunakan dalam memproduksi batik. Industri Batik Pring Sidomukti tergolong pada industri kecil yang mandiri dikarenakan industri ini tidak tergantung pada peranan pedagang perantara dan mampu memasarkan produksinya sendiri. Menurut Beratha (1982: 117) Industri kecil merupakan salah satu penunjang pembangunan di desa.

Para konsumen batik biasanya datang dan memesan batik langsung ke tempat produksi. Sehingga peran dari pembatik tidak hanya sebagai pembuat saja namun sekaligus sebagai pemilik.Segala bentuk keperluan industri mulai dari manajemen keuangan dan pemasaran dilakuan secara mandiri oleh para anggota itu sendiri. Adanya industri kecil mampu menunjang pada perubahan sosial ekonomi masyarakat. Industri kecil mampu menyerap tenaga kerja yang awalnya adalah pengangguran. Industri kecil di pedesaam lebih mengandalkan sistem kekeluargaan, sehingga hanya membutuhkan keahlian dan sistem distribusi juga sederhana.

Menurut Beratha (1982: 125) menjelaskan Industri kecil yang cocok dikembangkan di desa adalah jenis industri yang disesuaikan dengan kondisi desa yang bersangkutan. Desa Sidomukti selain mempunyai Industri Batik Sidomukti yang bergerak di bidang pemenuhan kebutuhan sandang dengan motif berdasarkan lingkungan, desa ini juga mempunyai industri anyaman dengan memanfaatkan 
Tumbuhan Pring yang tumbuh di lingkungan sekitar.

Pada awalnya, KUBE Mukti Rahayu mempunyai puluhan anggota yang berantusias, namun dikarenakan awalnya KUBE ini belum mampu berkembang, akhirnya banyak dari para warga untuk memutuskan keluar. Setelah berjalan sekitar satu tahun, KUBE ini mendapatkan angin segar dengan berdatangannya pesanan dari masyarakat Magetan. Lambat laun jumlah anggotapun semakin bertambah dikarenakan pendapatan yang didapatkan oleh para pembatik mengalami peningkatan hampir tiga kali lipat dari pendapatan sebelumnya.

Keberhasilan KUBE Mukti Rahayu kemudian menjadi inspirasi dan tekad baru warga Desa Sidomukti. Akhirnya, pada tahun 2006 Pak Tikno bersama warga mendirik KUBE yang kedua yang kemudian diberi nama Mukti Lestari. Pada dasarnya konsep dan motif antara kedua KUBE tersebut sama namun lokasi pembuatan berbeda. Anggota dari KUBE tersebut adalah sekitar 36 orang yang terdiri dari ibu-ibu yang telah berumah tangga.

Pada tahun 2014 warga bertekad kembali mendirikan KUBE baru yang diberinama Sri Tanjung. Namun, KUBE baru ini dikembangkan dengan menggunakan konsep yang berbeda dari dua KUBE sebelumnya. Perbedaan terletak pada kreasi motif dan pewarna yang digunakan oleh Sri Tanjung. Pewarna alam digunakan pada pembuatan batik sehingga warna dari batik yang baru akan lebih terlihat menarik dari yang sebelumnya. Anggota dari KUBE inipun diperuntukkan bagi para remaja Desa Sidomukti yang masih mempunyai semangat tinggi dan kretivitas yang tinggi pula.

Industri Batik Pring Sidomukti sudah berjalan sekitar 12 tahun namun perjalanan tidak berjalan mulus.Masih terdapat beberapa kendala yang dihadapi oleh Industri Batik Pring Sidomukti. Kendala yang dihadapi antara lain, tempat produksi yang kurang memadai, kuantitas tenaga kerja, permodalan, cuaca, dan pemasaran. Pasar masih menjadi kendala utama bagi industri ini begitu juga dengan faktor cuaca.Pada musim panas industri ini mampu memproduksi sekitar 500 lembar kain batik, sedangkan pada musim penghujan produksi menurun sekitar 350400 lembar kain batik perbulan.

Pemerintah sudah melakukan beberapa upaya untuk melestarikan Batik Pring antaralain, memberikan bantuan kepada masing-masing KUBE secara bertahap, membuat kebijakan kepada PNS untuk memakai Batik Pring Sidomukti yang diikuti kebijakan sekolah untuk mewajibkan memakai seragam Batik Pring Sidomukti pada siswa. Pemerintah terus melakukan promosi melalui media masa agar Batik Pring Sidomukti dapat dikenal oleh masyarakat luas.Pemerintah terus memberikan bantuan berupa permodalan 
dan pelatihan pada pengrajin batik sehingga mampu terus berkembang dan bersaing dengan yang lainnya.

\section{B. Perkembangan Motif Batik Pring} Sidomukti Kecamatan Plaosan Kabupaten Magetan.

Industri Batik Pring Sidomukti terus melakukan inovasi terhadap motif. Baik Pak Tikno maupun pengrajin berusaha untuk membuat desain baru yang mengena di pasaran dan mampu menarik perhatian masyarakat.Pembuatan motif batik $80 \%$ dibuat oleh Pak Tikno selaku pendiri dari Industri Batik Pring Sidomukti. Pengrajin juga diikutsertakan dalam pembuatan motif batik. Para pengrajin dituntut untuk berinovasi guna mendapatkan motif yang baru tetapi tetap tidak meninggalkan motif dasar yaitu Pring. Motif dasar diambil berdasarkan asal daerah dan makna yang terkadung dalam Pring.

Pembuatan motif Batik Sidomukti dipengaruhi oleh alam lingkungan yang banyak terdapat tumbuhan bambu. Keadaan alam sering menginspirasi dalam pembuatan motif. Ragam hias pada batik yang diciptakan oleh penciptanya dalam kehidupan sehari-hari, mereka melihat keadaan alam sekitarnya, termasuk flora dan fauna (Asmito, 1988: 30). Bentuk motif dari batik biasanya berbentuk hewan dan motif tumbuhan seperti Batik Sidomukti yaitu motif Pring yang banyak tumbuh di Desa Sidomukti. Awalnya motif batik dibuat untuk mengingatkan kita pada kekayaan dan kecintaan sang pembuat batik pada alam dan lingkungan sekitar. Hal ini tercermin dari hasil cipta rasa seni nenek moyang kita dengan membuat motif hewan dan motif tumbuhan (Goenadi, 2013: 4).

Pemilihan Pring sebagai motif juga dipengaruhi oleh makna yang terkandung dalam Tumbuhan Pring yaitu kerukunan dan kebersamaan. Mardiantoro, dkk (2013: 111) menyatakan bahwa:

Pring sedapur ciri khas motif
batik Kabupaten Magetan. Pring
(Bahasa Jawa) yang berarti Pring,
sedapur berarti kawanan atau
serumpun. Ciri yang menampakkan
suasana pedesaan yang banyak
tumbuh Pohon Pring, motif dasar
berupa lukisan rumpunan Pohon
Pring di setiap motifnya. Warna
merah dan biru mendominasi motif
Batik Magetan.

Selain itu, motif Pring ini mengandung beberapa makna, sebagai berikut:

1. Pring asalnya dari Dusun Papringan yang merupakan tempat berdirinya Industri Batik Sidomukti.

2. Pring sebagai lambang kebersamaan atau kerukunan karena Pring selalu bergerombol dan berumpun, tidak ada satupun jenis Pring yang hidup sendirian,

3. Pring menurut Sunan Kalijaga adalah deling artinya kendel eleng yang bermaksud bahwa manusia harusingat kepada yang maha pemberi hidup yang Maha Kuasa, 
4. Pring memiliki makna yang luar biasa, artinya ketika posisi Pring kaku dan keras bisa digunakan sebagai senjata tetapi ketika Pring diposisikan lemah bisa menjadi tali atau pengikat (Tikno, 2015).

Pring adalah tumbuhan atau pohon yang multiguna, artinya mulai dari akar sampai ranting, daun semua berguna bagi kehidupan dan semuanya bermanfaat. Terdapat beberapa motif yang telah dibuat dan diproduksi oleh Industri Sidomukti. Pada awal berdiri, motif batik yang dibuat adalah motif Batik Pring Sedapur dengan memasukkan unsur bambudi dalamnya dan terdapat motif bulan di tengah-tengah tumbuhan bambu.

Motif ini kemudian diperkenalkan kepada masyarakat melalui pameranpameran pada acara fashion show. Pemerintah juga memperkenalkan pada masyarakat dengan cara mewajibkan semua pegawai negeri sipil (PNS) menggunakan Batik Pring Sedapur sebagai seragam.

Seragam ini diberikan secara gratis oleh pemerintah sehingga semua pegawai negeri sipil (PNS) mendapatkan secara menyeluruh tanpa mengeluarkan uang. Masyarakatpun memberikan apresiasi pada Batik Pring yaitu dengan menerapkan kebijakan memakai seragam sekolah bermotif Batik Pring.

Motif ini merupakan perpaduan dari ornamen bambu dan bulan yang berada di bulan yang berada di antara batang bambu.
Dibuat pada tahun 2002 dan memiliki makna lambang kerukunan dan kebersamaan. Pembuatan dari motif ini adalah sebuah bentuk harapan agar masyarakat senantiasa menjaga kerukunan dan kebersamaan, sehingga akan tercipta masyarakat yang harmonis.

Motif kedua yang diciptakan adalah motif Pring Sulur pada tahun 2002 oleh Pak Tikno. Motif ini mengandung makna bahwa diperlukan sarana untuk bekerjasama dengan orang lain. Motif selanjutnya adalah Motif Pring Batu yang dibuat pada tahun 2003 yang mengkombinasikan antara ornament bambu dengan rumput dan batu yang berada di bawah batang bambu. Motif Pring batu mempunyai makna ketika menjalani hidup, manusia harus mempunyai pondasi yang kuat yaitu dengan pendidikan, semakin tinggi pendidikan maka pondasi yang dimiliki akan semakin kuat.

Motif yang ketiga adalah Motif Pring Bonggolan yang dibuat sekitar tahun 2004 yang didesain oleh Pak Tikno. Motif ini terdiri dari motif bonggolan dari Tumbuhan Pring. Motif Pring Bonggolan mempunyai makna filosofis, yaitu dalam sebuah kehidupan pasti ada pondasi layaknya Tumbuhan Pring yang mempunyai bonggol agar bisa berdiri. Di dalam pondasi kehidupan terkandung moral-moral kehidupan dan manusia harus berdiri pada pondasi yang benar yang mengandung moral yang baik. Tahun 2004 diciptakan motif yang memadukan antara hewan 
berupa burung dengan tanaman Bambu. Kemudian diberi nama Motif Pring Jalak Lawu yang terdiri dari Tumbuhan Pring yang tumbuh tegak di tengah dan disamping kanan kiri terdapat Tumbuhan Tambu yang tumbuh menyilang keluar. Pada Tumbuhan Pring terdapat dua Burung Jalak yang saling berhadapan.

Kemudian di bagian bawah tumbuh rumput dan di beri batu yang tertata rapi untuk pembatas tumbuhan. Pada motif ini terdapat sebuah harapan akan pentingnya pelestarian burung Jalak yang banyak terdapat di sepanjang jalan menuju Gunung Lawu, sehingga masyarakat akan lebih menyayangi binatang dan ikut melestarikannya.

Motif berikutnya adalah Motif Pring Ijen yang terdiri dari Tumbuhan Pring yang tumbuh menjulang ke atas.Tetapi Tumbuhan Pring ini hidup sendiri tanpa berumpun dengan Pring lainnya.Di bagian bawah Pring terdapat rumput yang berjejer rapi dan dipagari dengan batu-batuan. Motif ini memberikan pembelajaran bahwa dalam sebuah kehidupan, manusia adakalanya harus menyendiri untuk merenungkan diri dan mawas diri.

Maka dari itu, terkadang harus keluar dari kerumunan untuk memantapkan jati diri. Makna tersebut memberikan pembelajaran bahwasanya manusia harus meluangkan waktu untuk merenungkan diri agar kedepannya lebih baik. Motif Pring Sekar Jagad adalah motif yang mengingatkan masyarakat pada jagat raya. Motif ini terdiri dari beberapa tumbuhan yang berbeda tetapi hidup bersama dalam satu wadah. Makna yang terkandung pada motif ini adalah sebagai lambang kerukunan antara manusia yang berasal dari satu latar belakang maupun berbeda latar belakang yang merupakan ciptaan Tuhan yang harus saling membantu dan menghormati.

Berbeda macam jenis, suku dijadikan satu untuk hidup bersama. Makna motif tersebut memberikan pembelajaran bahwa dalam sebuah kehidupan manusia harus berbuat baik ke semua tanpa membeda-bedakan asal mereka. Motif selanjutnya adalah Motif Pring Sekar Melati yang terdiri dari tumbuhan Pring yang tumbuh tegak ke atas dan di samping kanan kiri terdapat tanaman bunga melati.

Di bagian bawah terdapat rumput yang tertata rapi. Motif ini mengandung makna bahwa meskipun manusia berbedabeda, berbeda agama, latar belakang, pendirian dan berada jauh satu sama lain, tetapi manusia tetap bisa untuk saling bekerjasama dan hidup bersama. Pada tahun 2008, motif yang berhasil diciptakan adalah motif Pring Bunga yang berfokus pada motif bunga yang terdapat di tengah motif Pring.

Pada motif ini terdapat harapan agar dengan adanya perumpamaan yang indah maka kerukunan dan kebersamaan akan terus dijaga. Tahun 2009 yang dikemudian dikembangkan oleh para pengrajin. Makna 
yang terkandung adalah sebuah kerukunan adalah sesuatu yang bisa dijadikan pendingin dan menciptakan kesejukan dalam sebuah kehidupan.

Motif yang selanjutnya adalah Motif Pring Cecek yang dibuat tahun 2010. Makna yang terkandung adalah kebersamaan dan kerukunan digambarkan layaknya tumbuhan Pring yang selalu hidup bersama. Motif berikutnya adalah Motif Pring Kuning yang terdiri dari Tumbuhan Pring Kuning yang hidup berumpun dan terdapat ornament rumput serta batu di bawah tumbuhan bambu. Makna yang terkandung adalah dalam sebuah kebersamaan itu akan lebih indah jika kita mampu menerima perbedaan yang mungkin lebih baik daripada kita.

Pada tahun 2011, Pak Tikno kembali membuat motif baru yang dinamakan motif Magetan kumandang. Motif ini mengandung harapan agar Magetan terkenal karena mempunyai potensi kerajinan, home industri, tumbuh-tumbuhan dan potensi hewan. Motif Pring Polos adalah motif yang dibuat pada tahun yang sama dengan motif Magetan kumandang. Terkandung makna bahwa dalam sebuah kehidupan harus dijalani secara sederhana, tidak boleh berlebih-lebihan.

Terselip harapan supaya manusia lebih bijak dalam menjalani sebuah kehidupan dengan menggunakan barang seperlunya saja. Pada tahun 2012, Pak Tikno membuat motif baru yang mengkombinasikan rumput di dalamnya. Pada motif ini terkandung makna bahwa terdapat hubungan antara satu makhluk dengan makhluk lainnya, sehingga kita harus saling menghormati.

Pak Tikno terus berinovasi demi menghasilkan motif yang mengena di hati. Motif Pring Gunungan menjadi motif yang melambangkan sebuah bumi atau jagad raya yang didalamnya terdapat unsur bumi, tanah, air, flora dan Fauna yang berasal dari gunung. Motif ini dibuat sebagai perwujudan dari Gunung Lawu yang terdapat di Desa Sidomukti.

Pada tahun 2013 Pak Tikno mencoba untuk memasukkan sebuah motif naga yang erat kaitannya dengan mitos Telaga Sarangan. Motif ini terdiri dari tumbuhan Pring yang tumbuh tegak ke atas dan di samping kanan kiri terdapat naga besar. Pada motif ini terdapat harapan agar Batik Sidomukti bisa menjadi seperti Naga yang disegani oleh banyak orang. Selain hewan, tumbuhan pun menjadi sumber inspirasi seperti pada motif Pring Bunga Krisan.

Motif ini mempunyai harapan bahwa dalam sebuah kehidupan, manusia harus berusaha menjadi indah dalam artian baik hati yang pada akhinya akan membuat dirinya menjadi indah seperti bunga krisan. Tahun 2014, diciptakan sebuah motif yang mewah dan gagah yang kemudian diberi nama motif Pring Parang Garuda. Motif ini terdiri dari tumbuhan Pring dan sayap dari 
garuda yang berada di kanan dan kiri Pring.Pembuatan motif ini juga ditujukan untuk melestarikan budaya, dan berharap batik Sidomukti bisa seperti Garuda yang gagah dan disukai banyak orang.

\section{Penutup}

\section{A. Kesimpulan}

Berdasarkan penelitian ini, maka dapat disimpulkan beberapa hal, yaitu:

1. Pendirian Industri Batik Pring Sidomukti dipelopori oleh Pak Tikno selaku kepala desa di Desa Sidomukti. Latar belakang pendirian kembali Industri Batik Pring Sidomukti adalah yang pertama, untuk menghidupkan kembali dan melestarikan kebudayaan nenek moyang. Kedua, untuk membuka lapangan pekerjaan baru bagi warga Desa Sidomukti dalam rangka mensejahterakan masyarakat dan memperbaiki taraf hidup masyarakat yang tergolong rendah.

2. Perkembangan motif Batik Pring Sidomukti sebagai berikut:

KUBE pertama didirikan pada tahun 2002 dan dinamakan dengan KUBE Mukti Rahayu yang beranggotakan 36 pembatik.Pada tahun 2006 didirikan KUBE baru yaitu KUBE Mukti Lestari yang beranggotakan 30 orang. Tahun 2014 didirikan lagi KUBE baru yaitu Sri Tanjung tetapi masih dalam tahap pelatihan dan belum berproduksi. Beberapa hal yang menghambat perkembangan Industri ini antara lain, faktor tempat produksi, cuaca, permodalan, dan pemasaran. Beberapa upaya yang dilakukan pemerintah dalam melestarikan Industri batik antara lain: mewajibkan PNS menggunakan Batik Pring sebagai seragam, diikuti dengan pihak sekolah yang mewajibkan siswa menggunakan seragam Batik Pring.

Pemerintah terus memberikan bantuan berupa permodalan dan pelatihan-pelatihan untuk menunjang perkembangan Industri Batik Pring.

3. Perkembangan Motif Batik Pring Sidomukti

Motif Batik Pring Sidomukti terinspirasi dari tumbuhan yang banyak tumbuh di Desa Sidomukti yaitu Tumbuhan Pring yang mempunyai makna filosofis pentingnya kebersamaan dan kerukunan manusia.

Motif Batik Sidomukti mengalami perkembangan diantaranya: Motif Batik Pring Sedapur, Pring Sulur, Bambu Batu, Pring Bonggolan, Jalak Lawu, Pring Ijen, Pring Sekar Jagad, Pring Sekar Melati, Pring Bunga, Pring Kipas, Pring Cecek, Pring Kuning, Magetan Kumandang, Pring Polos, Bambu Rumput, Pring Gunungan, Pring Naga, Pring Bunga Krisan, dan Pring Parang Garuda. Pembuatan Batik Pring Sidomukti masih menggunakan cara tradisional yaitu batik tulis. 


\section{B. Saran}

1. Bagi Industri Batik Sidomukti

a) Diharapkan melakukan evaluasi terhadap proses produksi baik dari segi peralatan dan kinerja proses pembuatan.

b) Melakukan promosi secara aktif sehingga Batik Sidomukti lebih dikenal masyarakat luas.

2. Bagi Para Pengrajin Batik Sidomukti

a) Diharapkan selalu melakukan perbaikan kinerja sehingga mampu memproduksi batik yang berkualitas.

b) Lebih berinovasi membuat motif batik yang lebih menarik sehingga mampu menarik konsumen yang lebih banyak.

3. Bagi Pemerintah

a) Hendaknya Pemerintah Kabupaten Magetan memberikan perhatian kepada Industri Batik Sidomukti sehingga industri batik ini mampu berkembang dan bersaing dengan Industri lainnya.

b) Memberikan perhatian dalam segi permodalan dan fasilitas yang memadai bagi para pembatik sehingga mampu memproduksi batik yang berkualitas dan mampu bersaing.

4. Bagi Penelitian Selanjutnya

Disarankan untuk peneliti selanjutnya agar lebih mendalami sejarah Batik Sidomukti dan masalah yang dihadapi oleh Industri Batik Pring Sidomukti. Oleh karena sejarah secara mendalam dan permasalahan yang dihadapi oleh industri ini belum begitu banyak dibahas baik dari fasilitas, permodalan, produksi, dan pemasaran. Selain itu, terdapat satu KUBE baru yang didirikan di Desa Sidomukti yang belum dibahas oleh peneliti dikarenakan masih dalam tahap pelatihan.

\section{Daftar Pustaka}

Asmito.1988. Sejarah Kebudayaan Indonesia. Jakarta: Dependikbud Direktorat Jendral Pendidikan Tinggi Proyek Pengembangan Lembaga Pendidikan Tenaga Pendidikan.

Beratha, I.N. 1982. Desa Masyarakat Desa dan Pembangunan Desa.Jakarta: Balai Aksara.

Dofa, A. A. 1996. Batik Indonesia .Jakarta: PT Golden Terayon Press.

Goenadi, D. 2013. Batik Indonesia. Bandung: CV. Teman Belajar.

Hamidin, A. S. 2010. Batik Warisan Budaya Asli Indonesia.Yogyakarta: Narasi.

Hamzuri. 1989. Batik Klasik. Jakarta: Djambatan.

Karmila, M. 2010. Ragam Kain Tradisional Nusantara (Makna, Simbol, dan Fungsi). Jakarta: Bee Media Indonesia.

Koentjaraningrat. 2002. Pengantar Ilmu Antropologi. Jakarta: PT Rineka Cipta.

Kusumawardhani, R. 2012. How To Wear: Bagaimana Mengenal Batik, Memilih, Merawat, dan Menyesuaikannya dengan Tubuh dan Warna Kulit. Jakarta: PT. Gramedia Pustaka.

Lisbijanto, H. 2013. Batik.Yogyakarta: Graha Ilmu.

Mardiantoro, G.T, dkk. 2012. Batik Jawa Timur, Legenda dan Kemegahan. Surabaya: Badan Perpustakaan dan Kearsipan Prov. Jatim. 
56 IJURNAL AGASTYA VOL 7 NO 2 JULI 2017

Saleh, I. A. 1986. Industri Kecil: Sebuah Tinjauan dan Perbandingan. Jakarta: LP3ES.

Wulandari, A. 2011. Batik Nusantara: Makna Filosofis, Cara Pembuatan, dan Industri Batik. Yogyakarta: C.V Andi Offset. 